Thennakoon, T.M.A.S., Mallawaarachchi, H, Rathnayake, R.M.D.I.M. and De Silva, L., 2021. Ensuring health and safety in petroleum built environment: The case of Sri Lanka. In: Sandanayake, Y.G., Gunatilake, S. and Waidyasekara, K.G.A.S. (eds). Proceedings of the $9^{\text {th }}$ World Construction Symposium, 9-10 July 2021, Sri Lanka. [Online]. pp. 326-335. DOI: https://doi.org/10.31705/WCS.2021.28. Available from: https://ciobwcs.com/papers/

\title{
ENSURING HEALTH AND SAFETY IN PETROLEUM BUILT ENVIRONMENT: THE CASE OF SRI LANKA
}

\author{
T.M.A.S. Thennakoon ${ }^{1}$, Harshini Mallawaarachchi' ${ }^{2}$, R.M.D.I.M. Rathnayake ${ }^{3}$ and \\ Lalith De Silva ${ }^{4}$
}

\begin{abstract}
The petroleum-built environment is an important area of concern, which mainly includes refinery and storage facilities. Since its hazardous nature leading unexpected accidents and disasters, the safety of petroleum-built environment has become a vital requirement to eliminate the hazards associated with the petroleum process. However, a comprehensive study on safe handling of petroleum products in Sri Lanka is not reported so far. Hence, this study aimed at enhancing the health and safety in handling process of petroleum products in refinery and storage facilities. A comprehensive literature review was initially conducted on the petroleum products handling process, and national and international safety guidelines. Case study method was used since this study requires an in-depth investigation. Two prominent cases for refinery and storage facilities were studied to collect the data. Content analysis technique was used to analyse the data. The findings revealed that Factories Ordinance, National Fire Protection Association (NFPA) Guideline, Occupational Health and Safety Assessment Series (OHSAS) standard, and National Institute of Occupational Safety and Health (NIOSH) Guideline are commonly considered in ensuring health and safety of petroleum-built environment. Further, the chronic deceases in lungs and heart, cancers, high noise generation, unwillingness to use personal protective equipment (PPE), bowser and wagon accidents, fuel fire risk, pipeline leakages, and water and soil pollution were highlighted as common health and safety issues in refinery and storage. Finally, various strategies were proposed to overcome the identified health and safety issues ensuring the health and safety of petroleum-built environment.
\end{abstract}

Keywords: Health and safety issues; Petroleum built environment; Refinery; Storage; Strategies.

\section{INTRODUCTION}

Petroleum products are generated through ancient plants and animals that have been compressed beneath the surface of the earth. Petroleum gas (LPG), premium motor spirit (PMS), automotive gas oil (AGO), high power fuel oil (HPFO), dual purpose kerosene (DPK) and aviation turbine kerosene (ATK) are mainly introduced as petroleum products (Essoka et al., 2006). The process of petroleum industry is divided into exploration,

\footnotetext{
${ }^{1}$ Department of Building Economics, University of Moratuwa, Sri Lanka, anupama.shakkyamali@gmail.com

${ }^{2}$ Department of Building Economics, University of Moratuwa, Sri Lanka, harshinim@uom.lk

${ }^{3}$ Department of Building Economics, University of Moratuwa, Sri Lanka, dulinirathnayake@ gmail.com

${ }^{4}$ Department of Building Economics, University of Moratuwa, Sri Lanka, lalithds@uom.lk
} 
extraction, refining, storage, transportation and marketing of the petroleum products (Amponsah and Opei, 2014). This study mainly focuses on petroleum built environment, which comprised of refinery and storage stages. Due to the complexity and the risk level in the process, human resource of the petroleum built environment needs special safety precautions (Stellman, 1998). Therefore, guidelines, standards and Acts are required for minimizing hazards and enhancing safety of the industry (Smith, 2013). Similarly, in Sri Lanka, petroleum built environment is one of the industries that has created various environmental damages, health and safety issues. For example, in 1995, the Orugodawaththa storage tanks were exploded due to terrorist attack and harmed the employees, environment and properties of the organization. The bowser accident at the Nellumdeniya station were contributed to major environmental and property damages (Ministry of Petroleum Industry, 2013). Even though, every country has their own national safety guidelines for the safe handling of petroleum products, many safety issues have been frequently reported in petroleum-built environment (Candreva et al., 2013). Moreover, majority of guidelines and standards are incapable of providing the adequate safety in petroleum-built environment covering the refinery and storage facilities in Sri Lanka (Samaratunga, 2013). Therefore, it is noteworthy necessity to develop a mechanism for ensuring health and safety of petroleum product handling process in refinery and storage facilities in Sri Lanka. Hence, the focus of this research paper is to investigate the existing health and safety guidelines, health and safety issues in the refinery and storage stages in order to propose strategies for ensuring health and safety in petroleum-built environment.

\section{LITERATURE REVIEW}

\subsection{Petroleum Products handling Process}

Petroleum can be classified as heavy or light depends on gravity on each product. High Sulphur content ( $0.5 \%$ and above) is concerned as the sour and low amount of Sulphur is called as sweet (Łużny, 2011). Crude oil is converted into the different products at the refinery level (Ceylon Petroleum Corporation, 2013). Petroleum industry undergoes two major processes, such as upstream and downstream. Yang et al. (2016) mentioned that the upstream process refers the part of the oil industry involved with finding oil fields and bringing oil up from the ground. The downstream process includes refining of various products, storage petroleum products, the transportation and retailing of petroleum products (Ambituuni et al., 2013).

Considering the above, the downstream process related to petroleum-built environment was selected in this research, which consists of refinery and storage facilities of petroleum products. Crude oil is purified and treated substance which use to remove unu sable substances in refinery while storage facilitates smooth out supply and demand discrepancies of petroleum products (Cheremisinoff, 2000).

\subsection{NATIONAL AND INTERNATIONAL GUIDELINES AVAILABLE FOR HEALTH AND SAFETY IN PETROLEUM BUILT ENVIRONMENT}

Edeskuty and Stewart (2013) highlighted three main issues in petroleum built environment, namely: health and safety issues, fire and explosions and environmental pollution. Moreover, authors mentioned that it is essential to establish guidelines and standards for safe handling petroleum products. Safety and health are ensured for safe 
handling of petroleum products by introducing proper Occupational Health and Safety Assessment Series (OHSAS) regulations. National Fire Protection Association (NFPA) is mainly based on preventing fire and safety issues in the handling of petroleum products. Further, National Institute of Occupational Safety and Health (NIOSH) standard is followed for preventing accidents, injuries and environmental issues (National Research Council, 2009). Functional Committee (2012) issued a permit for underground storage tanks and fittings of the storage tanks. Ravindran (2011) pointed out designing, construction, maintain of storage tanks. Workplace Law Group (2011) highlighted the requirements for the safe storage of used oil. Federal Road Safety Commission (FRSC) has established safety requirements and guidelines for articulated tanker operations in Nigeria that covers registration, licensing and emergency preparedness (Aroh et al., 2010). Festus et al. (2015) introduced petroleum licenses for filling stations.

In Sri Lanka, Petroleum Products Special Provisions Act No. 28 of 1961 basically govern the downstream petroleum industry. The regulation of the upstream petroleum industry is handled by the Petroleum Resources Act No. 26 of 2003 (Amaratunga, 2007). The safety issues in the refinery can be considered as a major area to develop a safety procedure for petroleum industry in Sri Lanka. The refinery unit of Sapugaskanda was established by Act No. 28 of 1961 and the unit distribute petroleum products throughout the island (Ceylon Petroleum Corporation, 2013). Ministry of Petroleum Industry (2013) described during refinery process, the organization is used various guidelines and standards for safe handling of petroleum products in petroleum industry namely, International Organisation for Standardisation (ISO) methods - ASTM D, OHSAS guidelines, Factories Ordinance No. 45 1942, NIOSH and NFPA. Factories Ordinance No. 45 1942, NIOSH, NFPA, Australian Standard and OSHAS 18001- 2007 guidelines are applied for enhancing safety in storage premises (Ministry of Petroleum Industry, 2013).

The conceptual framework summarizes the literature findings of the study as illustrated in Figure 1.

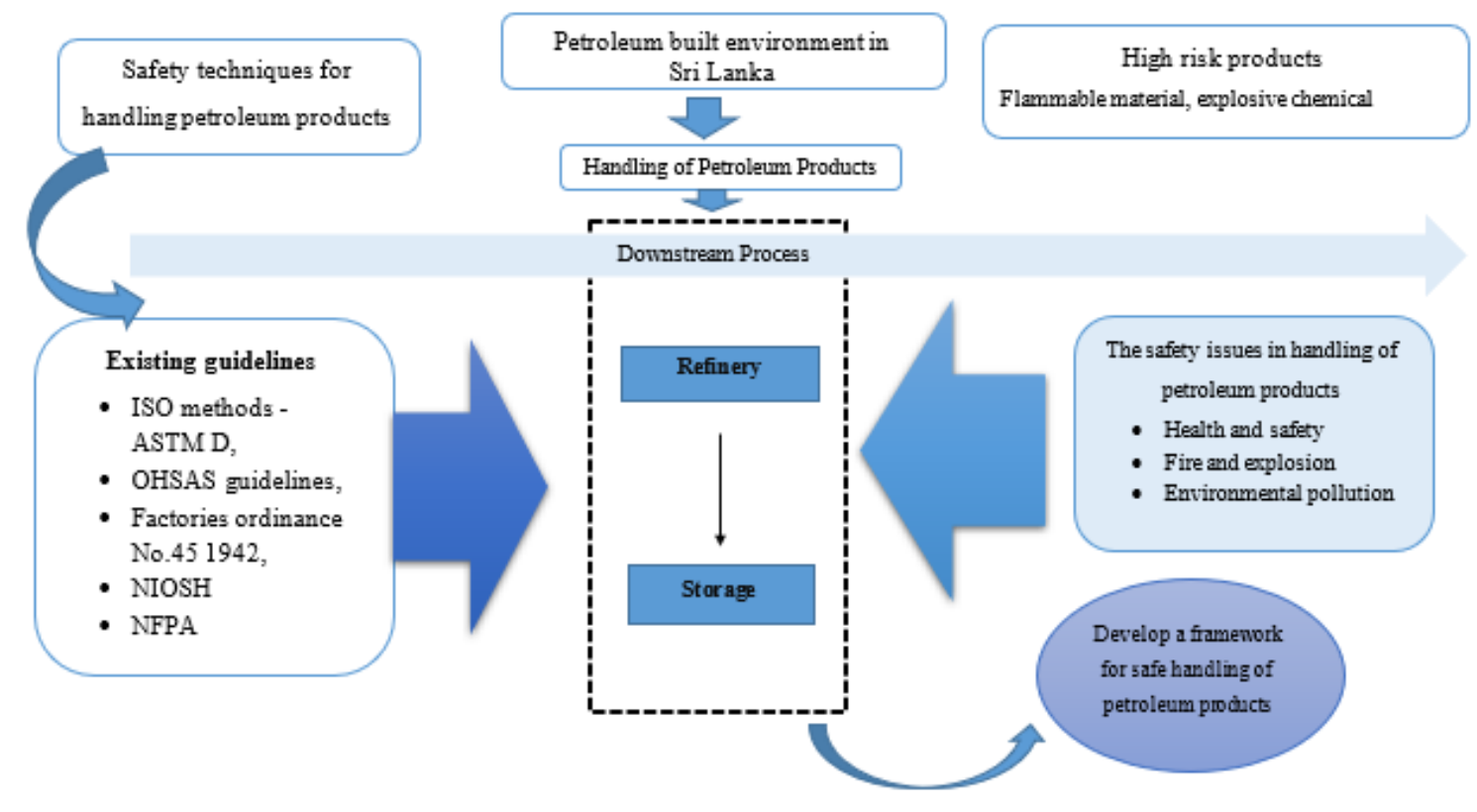

Figure 1: The conceptual framework 
Framework depicts safety standards and guidelines for handling petroleum products and safety issues relating to downstream petroleum process in Sri Lanka including refinery and storage. As a key implication of the research, this framework will be further enhanced by proposing strategies for ensuring health and safety in petroleum-built environment in Sri Lanka.

The methodology adapted in this research is presented below.

\section{RESEARCH METHODOLOGY}

A comprehensive literature review was conducted on 04 major areas, such as categories of petroleum products, handling process of petroleum products, safety guidelines available for handling of petroleum products, and the process of handling petroleum products in Sri Lanka. Case study method was adopted under qualitative phenomenon because the research problem required an in-depth investigation. According to Yin (2014), the number of cases can be one to eight depending on the nature of the research. Accordingly, 02 cases were studied by adopting the multiple case study design, which were selected based on the stages of petroleum products handling process. "Handling process of petroleum products' was the unit of analysis of this study. Table 1 presents the profile of selected cases.

Table 1: Profile of selected cases

\begin{tabular}{lcl}
\hline Case & Stage & \multicolumn{1}{c}{ Description } \\
\hline A & Refinery & $\begin{array}{l}\text { Capacity - } 50000 \text { barrels per stream day } \\
\text { No. of employees - } 1100\end{array}$ \\
& & Location - Western province \\
B $\quad$ Storage & $\begin{array}{l}\text { Capacity - Supported by } 11 \text { bulk deposits and handles } 12 \text { petroleum } \\
\text { products } \\
\end{array}$ \\
& No. of employees - 3 000 \\
& Location - Western province
\end{tabular}

Semi-structured interviews were conducted to investigate the existing safety guidelines, safety issues and to recognise probable strategies to ensure safety. Accordingly, 7 semistructed interviews were conducted with grade A and grade B level employees in the petroleum industry particularly in refinery and storage facilities as presented in Table 2.

Table 2: Profile of interviewees

\begin{tabular}{ccclc}
\hline Case & Stage & $\begin{array}{c}\text { Respondent } \\
\text { Code }\end{array}$ & \multicolumn{1}{c}{ Designation } & $\begin{array}{c}\text { Years of } \\
\text { Experience }\end{array}$ \\
\hline A & Refinery & A1 & $\begin{array}{l}\text { Environment, Health and Safety (EHS) } \\
\text { Supervisor }\end{array}$ & 10 \\
& & A2 & Safety Supervisor & 21 \\
& & A3 & Senior Operation Executive & 15 \\
B & Storage & B1 & Fire and Safety Officer & 16 \\
& & B2 & Manager - Premises and Engineering & 30 \\
& & B3 & Maintenance Manager & 10 \\
& & B4 & Assistant Manager & 32 \\
\hline
\end{tabular}


The collected data were analysed by using content analysis technique. Within case analysis was used to analyse the data collected in each case. The key findings derived through case analysis are presented below.

\section{RESEARCH FINDINGS AND ANALYSIS}

Existing safety guidelines, standards and procedures, and safety issues were first determined under refinery and storage of petroleum products. Moreover, various strategies to overcome the identified issues were proposed accordingly.

\subsection{CASE A - REFINERY}

\subsubsection{Existing Safety Guidelines, Standards and Procedures}

EHS Supervisor (A1) stated that the organisation has implemented various safety guidelines to minimise safety issues and to enhance the overall health conditions of occupants. Senior Operations Executive (A3) further mentioned that the main aim of these guidelines and regulations is to safeguard the organisation and its' occupants against the fire risk. EHS Supervisor (A1) highlighted that "ISO testing method checks oil samples before importing and transporting to the storage and retailing stations". All the interviewees in case A mentioned that Factories Ordinance No. 45 of 1942 is one of the regulations, which applicable for health and safety of employees in petroleum industry. ISO - ASTM D is involved as the main testing method for checking the quality of petroleum products. EHS Supervisor (A1) highlighted that "NFPA guidelines are involved to prevent hazards and to enhance the overall safety of occupants of the refinery stage". Moreover, OHSAS standard and NIOSH guideline provides a better management system to achieve production goals, occupational health and safety targets, and economic objectives while enhancing the safety of refinery stage.

As a basic safety precautions of the refinery stage, every employee must wear hearing protections and safety glasses while they are working. Senior Operations Executive (A3) stated that it is essential to wear hearing protections especially in areas with high noise generation. Further, EHS Supervisor (A1) mentioned that "safety glasses must be used when working on emery wheels, brushes, chipping or any other circumstances such as handling of hazardous chemicals". Other than that, respiratory protection considers as one of the high priorities. Senior Operations Executive (A3) buttressed that "refinery process is occurred in a high temperature levels therefore, employees always need to cover their whole body by fire resistant dresses". Moreover, motor vehicles can enter to the refinery premises only with a vehicle permit. Especially, this permit issuing system is used to provide clearance and safety permits for hot works, electrical operations, and confined space operations to minimise potential hazards.

\subsubsection{Safety Issues}

According to EHS Supervisor (A1), "chronic deceases in lungs and heart, and cancers can be identified as major health issues due to toxic vapours in the refinery premises. Stress related skin problems: dermal issues can be seen among employees who work for a long time in the refinery premises". As he further stated, toxic gaseous is a major cause for eye irritations. High noise generation causes for hearing losses for those who directly work with these hazardous conditions in refinery premises. Moreover, unwillingness to use PPE can also be considered as a major safety issue. Especially, bowser and wagons accidents can be identified as another common safety issue in the premises. Fuel fire, 
electrical wire short-circuits, pipeline leakage and environmental pollution: water and soil pollution can be commonly seen in refinery premises. Slips trips and falls issues are commonly occurred due to uneven surfaces and elevated working areas of the refinery premises.

\subsection{CASE B - Storage}

\subsubsection{Existing Safety Guidelines, Standards and Procedures}

Ceylon Petroleum Storage Terminal Ltd (CPSTL) safety rules and regulation is followed as one of the main guidelines of storage stage. Further, Factories Ordinance No. 45 of 1942 is also applied for this stage. To minimize the fire risk, NFPA Guidelines applicable for storage premises. Apart from that, National Electrical Code, National Fire Alarm and Signalling Code, and Guide for Fire and Explosion Investigations can be recognized as existing guidelines related to storage stage. Fire and Safety Officer (B1) stated that "Australian standard involves ensuring products, services and systems safety, Also, we use a safety code for electrical installations under Australian standard". OSHAS 18001-2007 and NIOSH Guideline can also be recognized as guidelines which are currently using in storage stage.

Maintenance Manager (B3) mentioned that "if employees want to do any welding or flame cutting work, they need to check previous welding work's flash point and also they must wear appropriate PPE. All the safety equipment including respiratory protections must be tested as a safety precaution. It is a must to wear PPEs (acid hood, rubber boots, face shields, fall-arrest equipment etc.) and non-flammable clothing when employees are engaging in maintenance and repairs such as cutting floor patches and repairing tank leaks". Further to case respondents, fire extinguishers, fire hose reels and emergency cooling systems can be highlighted as safety precautions against fire risk. Especially, hot works are not allowed in storage area due to highly flammable nature of the process. Safety permit needs to be obtained to conduct the maintenance of floating roof. Floating roof and protecting rim seals are damaged due to weather conditions, therefore, obtaining a safety permit is a mandatory requirement. To safeguard the electrical risk, various types of electrical equipment enclosures are used such as totally enclosed weatherproof sparking, totally enclosed weatherproof non-sparking and intrinsically safe nonflameproof enclosures.

\subsubsection{Safety Issues}

Fire and Safety Officer (B1) and Maintenance Manager (B3) stated that "health diseases, such as dermal issues, cancers and chronic in lungs and heart are common among bottom level employees due to the toxic vapour content in the petroleum products. High noise generation in pump house, inside the oil tanks and regarding maintenance of pipeline cause to hearing problems among employees". Moreover, vehicle accidents, unwillingness to wear PPE, fire risk, environmental pollution can be recognised as other common safety issues. Assistant Manager (B4) reported that "a lot of fuel loaded vehicles are entered and exited in daily basis. Our company always gives the instruction for drivers, but we can observe a high accidents rate mostly inside and outside in our organisation".

Tables 3 and 4 summarise the identified safety guidelines and standards, and health and safety issues in refinery and storage, respectively. 
Table 3: Existing safety guidelines and standards

\begin{tabular}{lcc}
\hline \multicolumn{1}{c}{ Existing Safety Guidelines, Standards } & \multicolumn{2}{c}{ Stage of petroleum process } \\
\cline { 2 - 3 } & Refinery & Storage \\
\hline ISO Testing: ISO -ASTM D & $\checkmark$ & \\
Factories Ordinance No. 45 of 1942 & $\checkmark$ & $\checkmark$ \\
NFPA guidelines & $\checkmark$ & $\checkmark$ \\
OHSAS Standard & $\checkmark$ & $\checkmark$ \\
NIOSH Guideline & & $\checkmark$ \\
Ceylon Petroleum Storage Terminal Ltd (CPSTL): & & $\checkmark$ \\
Safety Rules and Regulation & & $\checkmark$ \\
National Electrical Code & & $\checkmark$ \\
National Fire Alarm and Signalling Code & & $\checkmark$ \\
Guide for Fire and Explosion Investigations & & \\
Australian Code - Code for Electrical Installation & & $\checkmark$ \\
\hline
\end{tabular}

Table 4: Health and safety issues of refinery and storage stages

\begin{tabular}{lcc}
\hline \multicolumn{1}{c}{ Health and safety issue } & \multicolumn{2}{c}{ Stage of petroleum process } \\
\cline { 2 - 3 } & Refinery & Storage \\
\hline Chronic deceases in lungs and heart, and cancers & $\checkmark$ & $\checkmark$ \\
Toxic vapours in the premises & $\checkmark$ & \\
Stress related skin problems & $\checkmark$ & $\checkmark$ \\
High noise generation & $\checkmark$ & $\checkmark$ \\
Unwillingness to use PPE & $\checkmark$ & $\checkmark$ \\
Bowser and wagons accidents & $\checkmark$ & $\checkmark$ \\
Fuel fire risk & $\checkmark$ & \\
Electrical wire short-circuits & $\checkmark$ & $\checkmark$ \\
Pipeline leakage & $\checkmark$ & $\checkmark$ \\
Water and soil pollution & $\checkmark$ & \\
Slips trips and falls issues due to uneven surfaces and & & \\
Elevated working areas & & \\
Leakages in underground oil tanks & & \\
\hline
\end{tabular}

\subsection{STRATEGIES TO OVERCOME IDENTIFIED HEALTH AND SAFETY ISSUES}

In this step of the research attempts to explore the possible strategies to overcome the identified health and safety issues of refinery and storage stages. Moreover, interviewees suggested the following strategies not only to overcome the identified issues but also to enhance the overall health and safety condition of petroleum-built environment in Sri Lanka. Proposed strategies are summarised in Table 5. 
Table 5: Strategies to overcome issues in petroleum built environment

\begin{tabular}{|c|c|c|c|c|c|c|c|c|}
\hline \multirow{2}{*}{$\begin{array}{l}\text { Health and } \\
\text { safety issue }\end{array}$} & \multirow{2}{*}{$\begin{array}{l}\text { Strategies to overcome the } \\
\text { health and safety issue }\end{array}$} & \multicolumn{3}{|c|}{ Case A } & \multicolumn{4}{|c|}{ Case B } \\
\hline & & A1 & A2 & A3 & B1 & B2 & B3 & B4 \\
\hline \multirow{3}{*}{$\begin{array}{l}\text { Chronic } \\
\text { deceases in } \\
\text { lungs and heart, } \\
\text { and cancers }\end{array}$} & Designing job rotation & & $\checkmark$ & $\checkmark$ & & & $\checkmark$ & \\
\hline & $\begin{array}{l}\text { Assigning limitations to } \\
\text { working time }\end{array}$ & $\checkmark$ & & & $\checkmark$ & & & \\
\hline & Arranging medical check-up & & & & $\checkmark$ & & & \\
\hline \multirow{4}{*}{$\begin{array}{l}\text { Toxic vapours } \\
\text { in the premises }\end{array}$} & Designing job rotation & $\checkmark$ & & & & & & \\
\hline & $\begin{array}{l}\text { Assigning limitations to } \\
\text { working time }\end{array}$ & $\checkmark$ & & & & & & \\
\hline & $\begin{array}{l}\text { Critically adhering to the } \\
\text { Environmental Protection } \\
\text { License (EPL) }\end{array}$ & $\checkmark$ & & & & & & \\
\hline & $\begin{array}{l}\text { Measuring Volatile Organic } \\
\text { Compound (VOC) level time to } \\
\text { time }\end{array}$ & $\checkmark$ & $\checkmark$ & & & $\checkmark$ & & \\
\hline \multirow{3}{*}{$\begin{array}{l}\text { Stress related } \\
\text { skin problems }\end{array}$} & Designing job rotation & $\checkmark$ & & & $\checkmark$ & & & \\
\hline & $\begin{array}{l}\text { Assigning limitations to } \\
\text { working time }\end{array}$ & $\checkmark$ & & & $\checkmark$ & & & \\
\hline & Arranging medical check-up & $\checkmark$ & & & & & & \\
\hline \multirow{3}{*}{$\begin{array}{l}\text { High noise } \\
\text { generation }\end{array}$} & Designing job rotation & & & $\checkmark$ & & & & $\checkmark$ \\
\hline & $\begin{array}{l}\text { Assigning limitations to } \\
\text { working time }\end{array}$ & $\checkmark$ & & & & & & \\
\hline & $\begin{array}{l}\text { Installing suitable sound } \\
\text { insulation systems }\end{array}$ & & $\checkmark$ & & & & $\checkmark$ & \\
\hline \multirow[t]{3}{*}{$\begin{array}{l}\text { Unwillingness } \\
\text { to use PPE }\end{array}$} & $\begin{array}{l}\text { Enhancing knowledge } \\
\text { regarding PPE }\end{array}$ & & $\checkmark$ & & & $\checkmark$ & & \\
\hline & Conducting fit-tests & & $\checkmark$ & & $\checkmark$ & & & \\
\hline & $\begin{array}{l}\text { Inspecting and reporting about } \\
\text { employees who are not properly } \\
\text { wearing PPE }\end{array}$ & & & & & & & $\checkmark$ \\
\hline \multirow{2}{*}{$\begin{array}{l}\text { Bowser and } \\
\text { wagons } \\
\text { accidents }\end{array}$} & $\begin{array}{l}\text { Installing an in-vehicle } \\
\text { monitoring system }\end{array}$ & & & $\checkmark$ & & $\checkmark$ & & \\
\hline & $\begin{array}{l}\text { Providing clear visual } \\
\text { communication }\end{array}$ & & & & & & $\checkmark$ & \\
\hline \multirow[t]{2}{*}{ Fuel fire risk } & $\begin{array}{l}\text { Establishing and monitoring of } \\
\text { fire safety system }\end{array}$ & & $\checkmark$ & & $\checkmark$ & & & \\
\hline & $\begin{array}{l}\text { Collaborating with local fire } \\
\text { emergency response } \\
\text { community }\end{array}$ & & & & & & & $\checkmark$ \\
\hline $\begin{array}{l}\text { Electrical wire } \\
\text { short-circuits }\end{array}$ & $\begin{array}{l}\text { Conducting regular } \\
\text { maintenance and inspection } \\
\text { activities }\end{array}$ & & & $\checkmark$ & & & $\checkmark$ & \\
\hline
\end{tabular}




\begin{tabular}{|c|c|c|c|c|c|c|c|c|}
\hline \multirow{2}{*}{$\begin{array}{l}\text { Health and } \\
\text { safety issue }\end{array}$} & \multirow{2}{*}{$\begin{array}{l}\text { Strategies to overcome the } \\
\text { health and safety issue }\end{array}$} & \multicolumn{3}{|c|}{ Case A } & \multicolumn{4}{|c|}{ Case B } \\
\hline & & A1 & A2 & $\mathbf{A 3}$ & B1 & B2 & B3 & B4 \\
\hline $\begin{array}{l}\text { Pipeline } \\
\text { leakage }\end{array}$ & $\begin{array}{l}\text { Conducting regular } \\
\text { maintenance and inspection } \\
\text { activities }\end{array}$ & & & $\checkmark$ & & & $\checkmark$ & \\
\hline \multirow{3}{*}{$\begin{array}{l}\text { Water and soil } \\
\text { pollution }\end{array}$} & Reducing spills & & $\checkmark$ & & & & & \\
\hline & $\begin{array}{l}\text { Conducting proper actions for } \\
\text { freshwater management }\end{array}$ & $\checkmark$ & & & & & & $\checkmark$ \\
\hline & $\begin{array}{l}\text { Conducting awareness sessions } \\
\text { for employees regarding water } \\
\text { and soil pollution due to } \\
\text { petroleum }\end{array}$ & & & $\checkmark$ & & & & \\
\hline \multirow{3}{*}{$\begin{array}{l}\text { Slips trips and } \\
\text { falls issues due } \\
\text { to uneven } \\
\text { surfaces and } \\
\text { elevated } \\
\text { working areas }\end{array}$} & $\begin{array}{l}\text { Displaying safety signs in } \\
\text { hazardous areas }\end{array}$ & & $\checkmark$ & & $\checkmark$ & & & \\
\hline & $\begin{array}{l}\text { Installing safe lighting system } \\
\text { in different working } \\
\text { environments }\end{array}$ & & & $\checkmark$ & & & & \\
\hline & $\begin{array}{l}\text { Familiarising the work } \\
\text { environment for workers }\end{array}$ & & & & & & & $\checkmark$ \\
\hline \multirow{2}{*}{$\begin{array}{l}\text { Leakages in } \\
\text { underground } \\
\text { oil tanks }\end{array}$} & $\begin{array}{l}\text { Introducing new safety } \\
\text { standards for fuel storages }\end{array}$ & & & & & $\checkmark$ & & \\
\hline & $\begin{array}{l}\text { Conducting regular } \\
\text { maintenance and inspection } \\
\text { activities }\end{array}$ & & & $\checkmark$ & & & $\checkmark$ & \\
\hline
\end{tabular}

\section{CONCLUSIONS}

Due to its complexity and the high-risk level in nature, petroleum industry has become a hotspot for providing special precautions ensuring the health and safety of its employees, other occupants and general public. Similarly, in Sri Lanka, petroleum industry is one of the industries that has created various environmental damages, health and safety issues over the past years. Since, majority of guidelines and standards are incapable of providing the adequate safety in petroleum industry in Sri Lanka, it is worth to having a suitable health and safety guideline covering all the stages of petroleum products handling process. In developing a proper mechanism, this paper investigated the existing health and safety standards, regulations and guidelines, health and safety issues in the existing process, and strategies to overcome identified issues in refinery and storage stages. As derived through analysis, Factories Ordinance, NFPA Guideline, OHSAS standard, and NIOSH Guideline were highlighted as existing regulations and guidelines related to petroleum-built environment. Further, chronic deceases in lungs and heart, cancers, high noise generation, unwillingness to use PPE, bowser and wagon accidents, fuel fire risk, pipeline leakages, and water and soil pollution were recognised as common health and safety issues in both stages. Finally, the study was proposed probable strategies to overcome the identified health and safety issues in each stage in order to enhance the health and safety of petroleum-built environment. As the main implication, this study lays a way for approaching the betterment of health and safety in petroleum-built environment in Sri Lanka. 


\section{REFERENCES}

Amaratunga, R., 2007. Downstream petroleum industry in Sri Lanka. Colombo 03: SLEMA Annual Session.

Ambituuni, A., Amezaga, J., and Emeseh, E., 2013. Analysis of safety and environmental regulations for downstream petroleum industry operations in Nigeria: Problems and prospects. Environmental Development, 9, pp. 43-60.

Amponsah, R. and Opei, F.K., 2014. Ghana's downstream petroleum sector: An assessment of key supply chain challenges and prospects for growth. International Journal of Petroleum and Oil Exploration Research, 1(1), pp. 001-007.

Aroh, K., Ubong, I., Eze, C., Harry, I., Otong, J.U. and Gobo, A., 2010. Oil spill incidents and pipeline vandalization in Nigeria. Disaster Prevention and Management: An International Journal, 19(1), pp. 70-87.

Candreva, F., Rademaeker, E.D., Gowland, R., Isakov, A. and Oei, G.W., 2013. Safety guidelines and good industry practices for oil terminals. 23 .

Ceylon Petroleum Corporation., 2013. 2013 Annual report. Colombo 9: Ceylon Petroleum Corporation.

Cheremisinoff, N.P., 2000. Practical guide to industrial safety: Methods for process safety professionals. CRC Press.

Claxton, L.D., 2014. The history, genotoxicity, and carcinogenicity of carbon-based fuels and their emissions: 1. Principles and background. Mutation Research/Reviews in Mutation Research, 762, pp. 88-89.

Edeskuty, F.J. and Stewart, W.F., 2013. Safety in the handling of cryogenic fluids. Springer Science \& Business Media.

Essoka, P., Ubogu, A. and Uzu, L., 2006. An overview of oil pollution and heavy metal concentration in Warri area, Nigeria. Management of Environmental Quality: An International Journal, 17(2), pp. 209215.

Festus, M., Adebiyi, F. A. and Adeyemi., 2015. Determination of the contamination profile of groundwater in the vicinity of petroleum products retailing stations in Nigeria. Management of Environmental Quality: An International Journal, 26(2), pp. 250-269.

Functional Committee., 2012. Storage and handling of petroleum products at depots and terminals. Ministry of Petroleum and Natural Gas, Oil Industry Safety Directorate, India.

Łużny, R., 2011. In G. Gryglewicz (ed.), Chemical Technology: Raw Material and Energy Carriers, pp. 72-73. Wrocław University of Technology.

Ministry of Petroleum Industry, 2013. Annual performance report 2013. Colombo: Ceylon Petroleum Industry.

National Research Council., 2009. Traumatic injury research at NIOSH: Reviews of research programs of the National Institute for Occupational Safety and Health. Washington: National Academies Press.

Ravindran, S., 2011. Applying tank farm safety standards for petroleum storage tanks in India. Honeywell Process Solution, pp.1-16.

Samaratunga, R., 2013. Sri Lanka's petroleum industry: Policy, organization and challenges. Sri Lanka's Petroleum Industry, pp.39-41.

Smith, K., 2013. Environmental hazards: Assessing risk and reducing disaster. Routledge.

Stellman, J. M., 1998. Encyclopaedia of occupational health and safety: Industries and occupations. 3. International Labour Organization.

Workplace Law Group, 2011. Health and safety, premises and environment handbook 2012. Kogan Page Publishers.

Yang, R., Ozer, H., Imad, L., and Qadi, A., 2016. Regional upstream life cycle impacts of petroleum products in the United States. Journal of Cleaner Production, 139, pp. 1138-1149.

Yin R.K., 2014. Case study research, design and methods. $5^{\text {th }}$ ed. Sage: Los Angeles. 